\title{
A Search for Escherichia coli Antigens in Kidneys from Children with Urinary Tract Infection by Means of Immunofluorescence
}

\author{
B. KAIJSER, (31) S. HAGBERG, L. A. HANSON, AND S. OLLING \\ Departments of Immunology and Clinical Bacteriology, Institute of Medical Microbiology, Departments \\ of Pediatrics and Pediatric Surgery and Institute of Pathology II, University of Göteborg, Göteborg, Sweden
}

\section{Extract}

Kidneys from 14 children with diagnosis of recurrent pyelonephritis were studied for deposits of Escherichia coli. antigen, complement component $\mathrm{C} 3$, and immunoglobulincontaining cells using immunofluorescence.

$E$. coli $\mathbf{O}$ antigen was found in a scarred region in the kidney from only one patient. This was also confirmed by indirect hemagglutination inhibition using eluted antigen from the kidney.

In 10 of the 14 patients immunoglobulin G-as well as A-containing plasma cells were seen, while immunoglobulin M-containing cells were found in 6 kidneys. No deposits of complement were observed in any of the kidneys.

\section{Speculation}

The deposition of $E$. coli antigen in kidneys after pyelonephritis might be of significance for the development of kidney scarring.

Local antibody synthesis in the infected kidney might occur as a protection against the invading organisms.

It is well known that repeated urinary tract infections (UTI) in children, which are usually caused by $E$. coli, might induce parenchymal scarring $(5,14)$. Persisting $E$. coli antigen has been shown by Aoki et al. (3), Cotran et al. (8), and Sanford et al. (28) in animals with experimental pyelonephritis as well as by Aoki et al. (2) and Schwartz et al. (29) in adult humans using immunofluorescence technique and it has been suggested that this could be responsible for the slowly developing renal damage. On the basis of studies of $E$. coli antibodies in patients with UTI, Andersen (1) has also suggested that bacterial antigen might persist in the kidney for a period after an acute infection, causing persistently increased antibody titers.

The tissue-damaging effect of bacterial antigens deposited in the renal tissue might be influenced by antibodies. In this relation it is of special interest whether or not antibodies can be locally produced in the kidney. In an earlier report (12) we have shown higher levels of immunoglobulins in the urine of patients with UTI than in normal subjects and in recent studies we have seen secretory IgA antibodies against the infecting microorganisms in urine of patients with UTI (10). These antibodies are presumably locally formed. Lehmann et al. (23) and Miller et al. (24) have evidenced clearly in an experimental model that infected kidneys can produce immunoglobulins.

The aim of the present investigation was (1) to study, in children with bacteriologically and immunologically well defined UTI, whether or not $E$. coli $\mathrm{O}$ antigen could be identified in the kidney for a period after the acute infection, (2) to investigate whether immunoglobulin-containing cells could be found in the infectious focus of the pyelonephritis kidney, (3) to analyze whether deposits of the complement component $\mathrm{C} 3$ and immunoglobulins are present in the pyelonephritic scarred tissue.

\section{METHODS}

\section{PATIENTS}

Fourteen patients treated at the children's hospital, Göteborg, for recurrent urinary tract infections were analyzed. The clinical diagnosis of UTI was made as described earlier (18). Repeated quantitative urinary cultivations as well as $E$. coli antibody analyses of serum indicated the diagnosis of pyelonephritis. Kidney specimens were taken as biopsies or at partial nephrectomy performed because of local renal scarring thought to be the reason for repeated infections (Table 1). Cultivations were made by pressing at least four sections of the kidneys against blood agar plates. All kidney specimens were examined histologically and had histologic and macroscopic changes congruent with the diagnosis of chronic pyelonephritis according to the criteria of Heptinstall (13), including focal scarring of the renal tissue.

\section{CASE REPORT}

The following is a case report of patient $P R 690114$ shown to have deposits of $E$. coli antigen in scarred regions of the kidney (case 14 in Táble 1).

After the first attack of acute pyelonephritis in March 1969 caused by $E$. coli 04 , the patient was treated with sulfa. After this treatment, there was almost immediately relapsing asymptomatic infection with $E$. coli 04 ; this was treated with nitrofurantoin. X-ray examination showed a double renal pelvis on the right side and deformation of two renal calyces. There was decreased renal concentration capacity still persisting in May 1969. Two months' treatment with nitrofurantoin was then started and resulted in normalization of the concentration capacity. Two months after the treatment was finished asymptomatic bacteriuria with $E$. coli 04 was again present. This resulted in further therapy with nitrofurantoin until August 1970. X-ray examination May 1970 showed continued reduction of renal parenchyma as well as deformation of lower calyces on the right side and it was 


\begin{tabular}{|c|c|c|c|c|c|c|c|}
\hline \multirow{4}{*}{$\begin{array}{l}\text { Case no. } \\
\text { Case } 1\end{array}$} & \multirow{4}{*}{$\begin{array}{l}\text { Clinical diagnosis } \\
\begin{array}{l}\text { Pyelonephritis recidivans; } \\
\text { double ureter and renal } \\
\text { pelvis, right side }\end{array}\end{array}$} & \multirow{4}{*}{$\frac{\text { Operation }}{\text { Heminephrectomia }}$} & \multirow{4}{*}{$\begin{array}{l}\text { Time since last } \\
\text { known } E . \text { coli } \\
\text { infection, wk }\end{array}$} & \multicolumn{4}{|c|}{ Immunofluorescene results } \\
\hline & & & & \multirow{2}{*}{$\begin{array}{l}\text { Persisting } \\
\text { E. coli antigen }\end{array}$} & \multicolumn{3}{|c|}{ Cells containing Ig identified } \\
\hline & & & & & $\operatorname{IgG}^{2}$ & $\operatorname{Ig} A$ & $\operatorname{IgM}$ \\
\hline & & & & - & + & + & + \\
\hline Case 2 & $\begin{array}{l}\text { Pyelonephritis recidivans; } \\
\text { deformation of two renal } \\
\text { calyces, right side }\end{array}$ & $\begin{array}{l}\text { Resection of upper } \\
\text { part of right kidney }\end{array}$ & 52 & - & + & + & - \\
\hline Case 3 & $\begin{array}{l}\text { Pyelonephritis recidivans; } \\
\text { double ureter and renal } \\
\text { pelvis, right side }\end{array}$ & Heminephrectomia & 20 & - & + & + & + \\
\hline Case 4 & $\begin{array}{l}\text { Pyelonephritis recidivans; } \\
\text { double ureter and renal } \\
\text { pelvis, right side }\end{array}$ & Heminephrectomia & 12 & - & + & + & - \\
\hline Case 5 & $\begin{array}{l}\text { Pyelonephritis recidivans; } \\
\text { double ureter and renal } \\
\text { pelvis, left side }\end{array}$ & Heminephrectomia & 8 & - & + & + & - \\
\hline Case 6 & $\begin{array}{l}\text { Pyelonephritis recidivans; } \\
\text { double ureter and renal } \\
\text { pelvis, right side }\end{array}$ & Heminephrectomia & 4 & - & + & + & - \\
\hline Case 7 & $\begin{array}{l}\text { Pyelonephritis recidivans; } \\
\text { double ureter and renal } \\
\text { pelvis, right side }\end{array}$ & Heminephrectomia & 8 & - & + & + & + \\
\hline Case 8 & $\begin{array}{l}\text { Pyelonephritis recidivans; } \\
\text { deformation of the upper } \\
\text { renal calyx, right side }\end{array}$ & $\begin{array}{l}\text { Resection of the } \\
\text { upper part of right } \\
\text { kidney }\end{array}$ & 36 & - & + & + & + \\
\hline Case 9 & $\begin{array}{l}\text { Pyelonephritis recidivans; } \\
\text { renal calculus, left side }\end{array}$ & $\begin{array}{l}\text { Pyelolithotomy, bi- } \\
\text { opsy }\end{array}$ & 36 & - & - & - & - \\
\hline Case 10 & $\begin{array}{l}\text { Pyelonephritis recidivans; } \\
\text { double ureter and renal } \\
\text { pelvis, right side }\end{array}$ & Biopsy & $\begin{array}{l}\text { Asymptomatic } \\
\text { bacteriuria } \\
\text { (E. coli at the } \\
\text { same time as } \\
\text { biopsy) }\end{array}$ & - & - & - & - \\
\hline Case 11 & $\begin{array}{l}\text { Pyelonephritis recidivans; } \\
\text { myelomeningocele, ure- } \\
\text { terostomia }\end{array}$ & $\begin{array}{l}\text { Nephrectomia, right } \\
\text { side }\end{array}$ & $\begin{array}{l}12 \text { weeks } \\
\text { growth of } \\
\text { Proteus in the } \\
\text { kidney at the } \\
\text { time of opera- } \\
\text { tion }\end{array}$ & - & + & + & + \\
\hline Case 12 & $\begin{array}{l}\text { Pyelonephritis recidivans; } \\
\text { double ureter and pelvis, } \\
\text { right side; reflux }\end{array}$ & $\begin{array}{l}\text { Resection of upper } \\
\text { part of right kidney }\end{array}$ & 12 & - & - & - & - \\
\hline Case 13 & $\begin{array}{l}\text { Pyelonephritis recidivans; } \\
\text { reflux, right side }\end{array}$ & $\begin{array}{l}\text { Removing of the re- } \\
\text { flux, biopsy }\end{array}$ & 24 & - & - & - & - \\
\hline Case 14 & $\begin{array}{l}\text { Pyelonephritis chronic; } \\
\text { double renal pelvis (see } \\
\text { also Case Report) }\end{array}$ & Heminephrectomia & 52 & + & + & + & + \\
\hline
\end{tabular}

${ }^{1}$ In all patients the histologic examination was consistent with recurrent pyelonephritis. In no patient were deposits of complement component C3 shown.

${ }^{2} \mathrm{~A}$ slight cross-reactivity of fluorescein isothiocyanate-labeled anti-IgG with IgA was noted. 
decided to remove the scarred region (heminephrectomia dexter, September 1970).

\section{BACTERIAL STRAINS}

For E. coli strains from the WHO International Escherichia Centre, Statens Seruminstitut, Copenhagen, used, see Table 2. For morphologic studies the bacteria were cultivated on blood agar plates made with placental agar containing 5\% defibrinated horse blood and on Drigalski agar plates, made according to the method of Kauffmann, but with nutrient agar instead of placental broth and Danish agar (21).

$E$. coli strains isolated from patients were $\mathrm{O}$ grouped according to the method of Lincoln et al. (24).

\section{ANTIGENS}

Human kidney antigen and human liver antigen was prepared as described earlier (17).

\section{ANTISERA}

Antisera to whole bacteria (OKH antisera) as well as to the $\mathrm{O}$ antigen (O antisera) were prepared as described earlier (16). Absorptions. Absorptions of antisera as well as indirect hemagglutination titrations were performed as described earlier $(15,17)$. Mercaptoethanol treatment was performed according to the method of Hanson et al. (11).

Indirect Hemagglutination Inhibition. Indirect hemagglutination inhibition was performed as follows. The $E$. coli $\mathrm{O}$ antibody titer of a rabbit hyperimmunization serum was determined as measured by indirect hemagglutination. Thereafter the antiserum was absorbed repeatedly for $30 \mathrm{~min}$ at $37^{\circ}$ with antigen eluted from the kidney, and the antibody titer of the rabbit serum was determined and compared with the original value. Antigen was eluted from the kidneys in the following way. The kidney specimens were washed in buffered saline. Thereafter they were homogenized and repeatedly washed in buffered saline. The sediment was diluted in 2 volumes of $1 \mathrm{M}$ proprionic acid and stirred from $16 \mathrm{hr}$ at $+4^{\circ}$. After centrifugation the supernatant was dialyzed against 0.2


each at $+4^{\circ}$ for $24 \mathrm{hr}$. The supernatant obtained after centrifugation was concentrated and used as antigen.

Pyelonephritis Induction. Experimental, hematogenous pyelonephritis was induced in rabbits as described earlier (19).

\section{IMMUNOFLUORESCENCE TECHNIQUE}

The kidney specimens were divided into two portions. Ore was fixed in formalin $(10 \%)$ and sections of this were stained with hematoxylin and eosin and examined by light microscopy.

The other portion was paraffin embedded as described by Sainte-Marie (27) and was used for immunofluorescence

Table 2. Escherichia coli strains from WHO International Escherichia Centre, Statens Seruminstitut, Copenhagen, Denmark, used in this study

\begin{tabular}{cc}
\hline \multicolumn{1}{c}{ Serotype } & Seruminstitute designation \\
\hline $01: \mathrm{K} 1: \mathrm{H} 7$ & $\mathrm{U} 5 / 41$ \\
$02: \mathrm{K} 1: \mathrm{H} 4$ & $\mathrm{U} 9 / 41$ \\
$04: \mathrm{K} 3: \mathrm{H} 5$ & $\mathrm{U} 4 / 41$ \\
$06: \mathrm{K} 13: \mathrm{H} 1$ & $\mathrm{Su} 4344 / 41$ \\
$07: \mathrm{K} 1: \mathrm{H}-$ & $\mathrm{Bi} 7509 / 41$ \\
$08: \mathrm{K} 8: \mathrm{H} 4$ & $\mathrm{G} 3404 / 41$ \\
$014: \mathrm{K} 7: \mathrm{H}-$ & $\mathrm{Su} 4411 / 41$ \\
$018: \mathrm{K} 76: \mathrm{H} 14$ & $\mathrm{~F} 10018 / 41$ \\
$022: \mathrm{K} 13: \mathrm{H} 1$ & $\mathrm{E} 14 \mathrm{a}$ \\
$075: \mathrm{K} ?: \mathrm{H} 5$ & $\mathrm{E} 3 \mathrm{~b}$ \\
\hline
\end{tabular}

analyses. All specimens were tested for $(A)$ deposits of $E$. coli $\mathrm{O}$ antigen, $(B)$ presence of immunoglobulin-containing cells and $(C)$ deposits of the complement component $\mathrm{C} 3$ in the kidneys.

A. The indirect method was used, with a battery of the different rabbit antisera corresponding to the $E$. coli strains mentioned above (OKH antisera and $\mathrm{O}$ antisera). These were antisera against the $E$. coli strains with the most common $O$ antigens as well as $\mathrm{K}$ antigens found in UTI $(1,9)$. fluorescein isothiocyanate-labeled antirabbit immunoglobulin from sheep was supplied by the State Bacteriological Laboratory, Stockholm. It contained $10 \mathrm{mg}$ protein $/ \mathrm{ml}$ and had a molar $F / P$ ratio of 2.5 and was used in a dilution of $1 / 10$. The positive controls used were: (1) sections of paraffin-embedded boiled as well as formalin-killed homologous $E$. coli bacteria; (2) pyelonephritis kidneys from rabbits known to contain live bacteria when the paraffin embedding started (both direct and indirect immunofluorescence technique); (3) absorption of $E$. coli antisera with a heterologous $E$. coli strain; (4) absorption of antisera with human kidney antigen, as well as human liver. The following negative controls were run: (1) normal rabbit serum used instead of hyperimmune serum; (2) absorption of the $E$. coli antiserum with the homologous $E$. coli strain; (3) incubation of sections with unlabeled anti-rabbit immunoglobulin after incubation with $E$. coli antiserum but before FITC-labeled anti-rabbit immunoglobulin; (4) FITC-labeled anti-rabbit immunoglobulin used as direct technique (in a few experiments a faint fluorescence of human kidney was seen using FITC-labeled anti-rabbit immunoglobulin; however, this could be eliminated by absorption with human kidney antigen); (5) sections from two kidneys from patients without known UTI, one from a 2-year-old girl with tumor of the kidney and one from a 6-year-old boy nephrectomized because parts of the kidney were badly damaged in a car accident. The used kidney sections were normal on histologic examination.

B. Presence of immunoglobulin-containing cells in the kidney sections was tested by the direct technique using FITC-labeled sheep anti-human immunoglobulin G, A, and M, respectively. The antisera were applied by the State Bacteriological Laboratory, Stockholm. They had the following protein concentrations: $7.0 \mathrm{mg} / \mathrm{ml}, 9.5 \mathrm{mg} / \mathrm{ml}$, and $7.0 \mathrm{mg} / \mathrm{ml}$; and molar $F / P$ ratios of $2.5,3.1$, and 3.4. They were used in dilutions of $1 / 10$. The specificity of the antisera was guaranteed by the manufacturer using immodiffusion methods as controls. However, in recent control experiments kindly performed by Brandtzaeg, who employed artificial sections of selected antigenicity (6), it was shown that the FITC-labeled anti-IgG also reacted faintly with IgA. The FITC-labeled anti-IgA and anti-IgM were specific.

C. Deposits of the complement component $\mathrm{C} 3$ in the infected kidneys were tested by the direct technique using a FITC-labeled sheep anti-C3 serum produced according to the method of Müller-Eberhard et al. (26) and kindly supplied by Dr. G. Westberg, Göteborg. Incubation with unlabeled antiserum before the FITC-labeled antiserum was used as the negative control.

All immunofluorescence samples were studied by a Leitz Orthoplan microscope, equipped for incident illumination, with a high pressure mercury vapor lamp (Osram HBO-200). Primary filters were BG 38, BG 12, and KP 490 and secondary was $\mathrm{K}$ 510. Photos were taken with Kodak Tri-X or Ektachrome high speed.

\section{RESULTS}

\section{TESTS FOR PRESENCE OF E: COLI ANTIGENS}

In only 1 of the 14 kidneys from patients with pyelonephritis (case 14 in Table 1; see also Case Report) was E. coli antigen identified by immunofluorescence in scarred regions 
(Fig. 1). The controls were unremarkable. The antigen in this patient was $E$. coli 04 . At the time of the operation all urine cultures as well as cultures directly from sections of the kidney were negative. All other examined kidneys were negative analyzed with anti-O as well as anti-OKH serum. In all kidneys both scarred and nonscarred regions were analyzed. A further indication of $E$. coli 04 antigen in the kidney was given by the results of indirect hemagglutination inhibition. Extracted antigen from the kidney inhibited $E$. coli 04 antibodies in a rabbit antiserum five titer steps as compared with no inhibition when an extract from normal kidneys was used. In addition, a single injection in rabbit of $0.1 \mathrm{ml}$ of the extracted kidney antigen gave a marked $E$. coli 04 antibody response. Furthermore, the $E$. coli 04 antibody titer of the patient's serum was slightly increased, $1 / 512$ before and $1 / 64$ after reduction with $\beta$-mercaptoethanol. Extracts from all other kidneys were negative in the indirect hemagglutination inhibition tests, using seven different $\mathrm{O}$ antigen-antibody systems, that is $E$. coli 01 , 04, 06, 07, 08, 018, and 075 antigens, and corresponding antibodies. Most of the kidneys, however, could to some extent inhibit $E$. coli 02 antibodies; this was related presumably to the cross reactivity between human kidney and E. coli 02 (17).

\section{TESTS FOR PRESENCE OF IMMUNOGLOBULIN-CONTAINING} CELLS OR DEPOSITS OF $\mathrm{C} 3$

Ten of the 14 kidneys had IgG-and/or IgA-containing cells in the infected part of the kidneys (Fig. 2 and Table 1). IgM-containing cells were found in six of the kidneys. In most cases immunoglobulin could also be seen in tissue outside the cells. In none of the kidneys was the complement component C3 found.


Fig. 1. Indirect immunofluorescence studies of a patient with chronic pyelonephritis (case 14, Table 1). A: positive fluorescence in a scarred region using rabbit anti-E. coli 04 and fluorescein isothiocyanate-labeled anti-rabbit immunoglobulin. Three glomeruli and some tubuli are seen. $B$ : negative control after absorption of rabbit anti-E. coli 04 with $E$. coli 04 bacteria $(\times 400)$. 


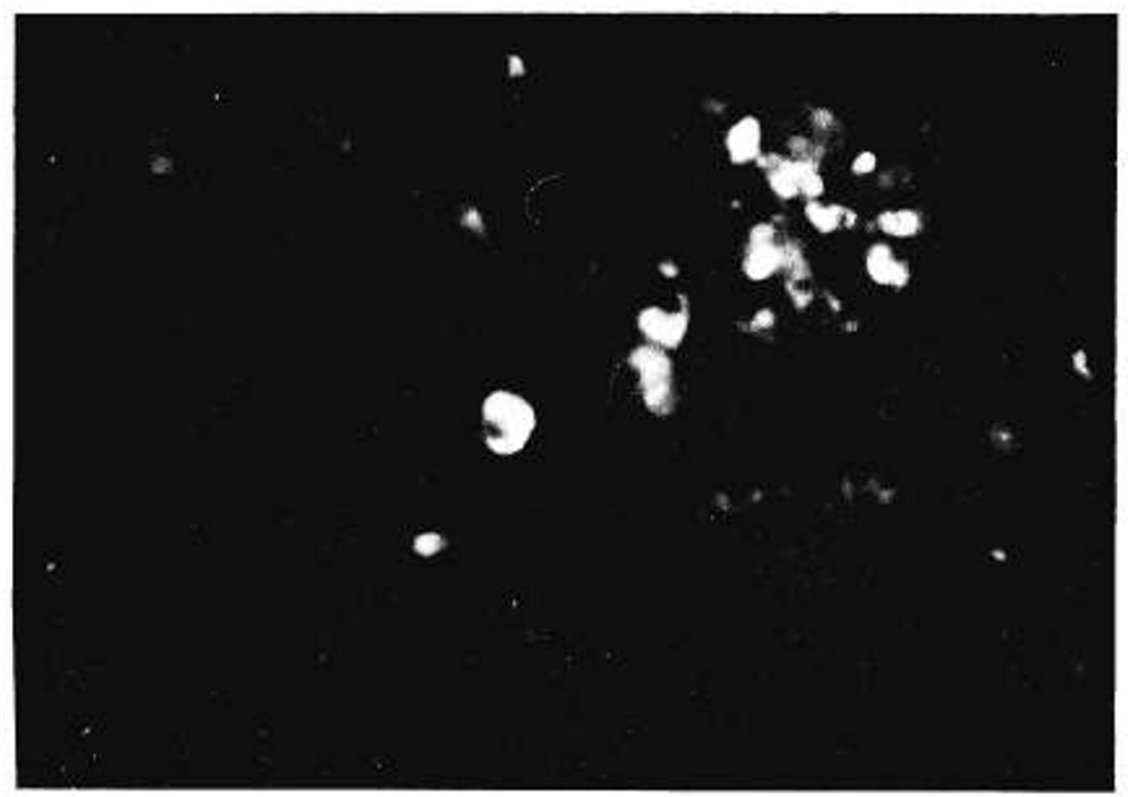

Fig. 2. Direct immunofluorescence studies of a patient with chronic pyelonephritis. Immunoglobulin-containing cells are seen using fluorescein isothiocyanate-labeled anti-human $\operatorname{Ig} \mathrm{A}(\times 540)$.

\section{DISCUSSION}

In only 1 out of the 14 kidneys with the histologic and clinical diagnosis of recurrent pyelonephritis did we find $E$. coli $\mathrm{O}$ antigen using immunofluorescence as well as hemagglutination inhibition technique. The fluorescence in the positive case was presumably specific since absorption of $E$. coli antiserum with heterologous $E$. coli strains as well as human kidney and liver antigen did not affect it. Furthermore, after absorption with boiled $E$. coli 04 bacteria, no fluorescence was seen. Thus the fluorescence could not possibly be the result of cross-reactive antibodies between $E$. coli and human kidney and, in fact, cross-reactions seem to be limited to $E$. coli 02,014 , and 022 strains (17).

The low frequency of remaining $E$. coli antigen after pyelonephritis is at variance with the findings of Aoki et al. (2) in adults using the immunofluorescence technique only. They used FITC-labeled antiserum to $E$. coli 014 , i.e., antibodies to the common antigen, CA, described by Kunin et al. (22). We also tested antiserum to the $E$. coli 014 , and this was negative in all kidneys. Aoki et al. (2) used freezing microtomy while we used the paraffin embedding technique described by Sainte-Marie (27) including fixation with $95 \%$ ethanol. These two procedures for preparing the kidneys might give different results and the former technique is perhaps more gentle to the kidneys. However, since the $E$. coli $\mathrm{O}$ antigen is known to be rather resistant and should not be affected by treatment of specimens according to Sainte-Marie, there should be no great differences between the results obtained with the one or the other method. Furthermore, in control experiments with paraffin-embedded rabbit kidneys, taken while $E$. coli bacteria were isolated from the parenchyma, it was possible to show bacteria by immunofluorescence. Also experiments with paraffin-embedded bacteria were positive.

Although Aoki et al. thus found a rather high frequency of positive kidney samples, Schwartz et al. (29) noticed recently very few cases of kidneys positive for $E$. coli antigen using approximately the same technique. They believed, however, that this most probably was due to different sensitivity of the modifications of the procedures.

The rarity of persisting $E$. coli antigen in kidneys seen in the present material might also be due to a long time lapse since the last infection. In animal experiments, however, antigen has been shown for several months after infection $(3,7,8,20,28)$, and in most of our patients there were only a few months between the last infection period and the operation. Furthermore, Aoki et al. (2) found residual bacterial antigen in kidneys from adults known to have been free of signs of infection for some years. Another explanation of our low frequency of positive cases could be that the 10 different antisera used in these investigations might be too few to cover all of the $E$. coli infections. On the other hand, many investigations have shown that strains of the corresponding $O$ groups cause between 50 to $75 \%$ of $E$. coli UTI in children (1).

The consequences of remaining $E$. coli antigens in renal parenchyma might be greater in children since it is shown that the growing kidneys, at least in mice, are much more sensitive to infection and scarring or parenchymal reduction than adult kidneys (4).

The presence of immunoglobulin-containing cells in the infected kidneys supports the opinion that immunoglobulins can be produced locally in infected kidneys, which fits with the earlier findings of higher immunoglobulin levels in the urine of patients with pyelonephritis as compared with normal subjects (2), as well as the appearance of secretory $\operatorname{IgA}$ antibodies in urine of patients with UTI (10). It is also in agreement with the results of studies of experimental pyelonephritis in rabbits by Lehmann et al. (23) and Miller et al. (25).

\section{SUMMARY}

Kidneys from 14 patients with the clinical and histopathologic diagnosis of chronic pyelonephritis were studied for deposits of $E$. coli antigen, complement component $\mathrm{C} 3$, and immunoglobulin-containing cells using the immunofluorescence technique. Kidney specimens were taken as biopsies or during operation performed because of local renal scarring presumably caused by repeated infections.

In one of the kidneys $E$. coli $\mathrm{O}$ antigen was found in scarred regions while all other kidneys were negative. The presence of the $E$. coli antigen was also shown by indirect hemagglutination technique using eluted antigen from the kidney.

Immunoglobulin $\mathrm{G}$ - and A-containing plasma cells were found in 10 of 14 kidneys, whereas immunoglobulin M-containing cells were identified only in 6 . 
In none of the kidneys were deposits of $\mathrm{C} 3$ revealed.

\section{REFERENCES AND NOTES}

1. Anderson, H.-J.: Clinical studies on the antibody response to $E$ coli O-antigens in infants and children with urinary tract infection, using a passive haemagglutination technique. Acta Paediat. Scand. Suppl., 180 (1968).

2. Aoki, S., Imamura, S., Aoki, M., and McCabe, W. R.: Abacterial and bacterial pyelonephritis: Immunofluorescent localization of bacterial antigen. New Engl. J. Med., 281: 1375 (1969).

3. Aoki, S., Merkel, M., Aoki, M., and McCabe, W. R.: Immunofluorescent localization of bacterial antigen in pyelonephritis. I. The use of antisera against the common enterobacterial antigen in experimental lesions. J. Lab. Clin. Med., 70: 204 (1967).

4. Asscher, A. W., and Chick, S.: Increased susceptibility of the kidney to ascending Escherichia coli infection following unilateral nephrectomy. Brit. J. Urol., 44: 202 (1972).

5. Bergström, T.: Sex differences in childhood urinary tract infection. Arch. Dis. Childhood, 47: 227 (1972).

6. Brandtzaeg, P.: Evaluation of immunofluorescence with artificial sections of selected antigenicity. Immunology, 22: 177 (1972)

7. Cotran, R. S.: Retrograde Proteus pyelonephritis in rats: Localization of antigen and antibody in treated sterile pyelonephritis kidneys. J. Exp. Med., 117: 813 (1963).

8. Cotran, R. S., Thrupp, L. D., Haji, S. N., Zangwill, D. P., Vivaldi, E., and Kass, E. H.: Retrograde E. coli pyelonephritis in the rat: A bacteriologic pathologic and fluorescent antibody study. J. Lab. Clin. Med., 61: 987 (1963).

9. Grüneberg, R. A., Leigh, D. A., and Brumfitt, W. Z.: Escherichia coli serotypes in urinary tract infections: Studies in domiciliary ante-natal and hospital practice. In: F. O'Grady and W. Brumfitt: Urinary Tract Infection, p. 68 (Oxford University Press, London, 1968).

10. Hanson, L. A., Ahlstedt, S., Carlsson, B., Jodal, U., Lindberg, U., and Soul, A.: Studies of secretory antibodies to $E$. coli in human urine compared to the serum antibody content. Proceedings of the International Symposium of Immunoglobulin A System, Birmingham, Alabama (in press).

11. Hanson, L. \&., Holmgren, J., Jodal, U., and Kaijser, B.: Characterization or precipitating antibodies to $E$. coli antigen in infants and children with acute pyelonephritis. Clin. Exp. Immunol., 8: 573 (1971).

12. Hanson, L. A., Holmgren, J., Jodal, U., Kaijser, B., Lönnroth, I., and Wadsworth, C.: Immunglobulins in urines of children with urinary tract infections. In: The Secretory Immunologic System. Proceedings of the Conference on The Secretory Immunologic System, pp. 367-383, Florida, 1969, United States Department of Health, Education and Welfare, National Institutes of Health, 1971.

13. Heptinstall, R. H.: Pathology of the Kidney, Ed. 1 (Little, Brown, Boston, 1966)

14. Hodson, C. J., and Wilson, S.: Natural history of ehronic pyelonephritic scarring. Brit. Med. J., 2: 191 (1965).

15. Holmgren, J.: Studies of methods for quantitation of agglutinins

Copyright $\odot 1974$ International Pediatric Research Foundation, Inc. and precipitins to Escherichia coli $\mathrm{O}$ and $\mathrm{K}$ antigens. Int. Arch. Allergy, 37: 480 (1970).

16. Holmgren, H., Eggertsen, G., Hanson, L. A., and Lincoln, K.: Immunodiffusion studies on Escherichia coli. 1. Identification of $\mathrm{O}, \mathrm{K}$ and $\mathrm{H}$ antigens in an 06 strain. Acta Pathol. Microbiol. Scand., 76: 304 (1969).

17. Holmgren, J., Hanson, L. A., Holm, S. E., and Kaijser, B.: An antigenic relationship between kidney and certain Escherichia coli strains. Int. Arch. Allergy, 41: 463 (1971).

18. Kaijser, B.: Immunology of Escherichia coli: $\mathrm{K}$ Antigen and it's relation to urinary tract infection. J. Infect. Dis., 127: 670 (1973).

19. Kaijser, B., and Olling, S.: Experimental hematogenous pyelonephritis due to Escherichia coli in rabbits: The antibody response and it's protective capacity. J. Infect. Dis., 128:41 (1973).

20. Kass, E. H.: Bacterial antigen in the kidney. New Engl. J. Med. 281: 1420 (1969)

21. Kauffmann, F.: The bacteriology of Enterobacteriaceae, Ed. 2 (Munksgaard, Copenhagen, 1966).

22. Kunin, C. M.: Separation, characterization and biological significance of a common antigen in Enterobacteriaceae. J. Exp. Med, 118: 565 (1963).

23. Lehmann, J. D., Smith, J. W., Miller, T. E., Barnett, J. A., and Sanford, J. P.: Local immune response in experimental pyelonephritis. J. Clin. Invest., 47: 2541 (1968).

24. Lincoln, K., Lidin-Jansson, G., and Winberg, J.: Resistant urinary infections resulting from changes in resistance pattern of faecal flora induced by sulphonamide and hospital environment. Brit. Med. J., 3: 305 (1970).

25. Miller, T. E., Smith, J. W. and Sanford, J. P.: Antibody synthesis in kidney, spleen and lymph nodes in acute and healed focal pyelonephritis. Brit. J. Exp. Pathol., 52: 678 (1971).

26. Müller-Eberhard, H. J., Nilsson, U., and Aronsson, T.: Isolation and characterization of two $\beta$ I glucoproteins of human serum. J. Exp. Med., 111: 201 (1960).

27. Sainte-Marie, G.: A paraffin embedding technique for studies employing immunofluorescence. J. Histochem. Cytochem., 10 : $250(1962)$.

28. Sanford, J. P., Hunter, B. W., and Donaldson, P.: Localization and fate of Escherichia coli in hematogenous pyelonephritis. J. Exp. Med., 116:285 (1962).

29. Schwartz, M. M., and Cotran, R. S.: Common enterobacterial antigen in human chronic pyelonephritis and interstitial nephritis. An immunofluorescent study. New Engl. J. Med., 289: 830 (1973).

30. The skillful technical assistance by Mrs. Ingela Delgado and Mrs Eva Âgren is very much appreciated. We are also grateful to the operating staff at the Children's Hospital, Göteborg, for their valuable assistance. Furthermore, we thank Dr. Per Brandtzaeg, Oslo, for his kindness in testing the specificity of some of our FITC-labeled antisera. The investigation was supported by grants from the Faculty of Medicine. University of Göteborg, and the Swedish Medical Research Council (19X-215).

31. Requests for reprints should be addressed to: B. Kaijser, M.D., Institute of Medical Microbiology, Guldhedsgatan 10, 41346 Göteborg, Sweden.

32. Accepted for publication July 15, 1974. 